\title{
Best Practices Application in the Development of Industry in Russia
}

\author{
Alexander Demidenko ${ }^{1}$, Anastasia Kramar $^{1}$, Igor Demidenko $^{1}$, Alexander Demidenko ${ }^{1}$ \\ ${ }^{1}$ Bryansk State Technical University, Russia
}

\begin{abstract}
This article is devoted to the analysis of the problems of the Russian economy in modern conditions, in particular, the technical and technological backwardness of Russia from the developed countries. The analysis of the reasons for the low level of competitiveness of the national economy has been carried out, and ways of its possible improvement have been investigated. The necessity of changing the export-raw model of economic development, based on the accelerated increase of fuel and raw materials exports, on the model based on the production of high-tech competitive products is shown. A study of the world's best practices in the development of industry and the agro-industrial complex has been conducted, and statistics of economic indicators of other countries is given. This article analyses the results obtained by these countries. Also, the most effective principles of economic management, which could be applied in Russia are identified. It is substantiated that the Russian Federation needs to intensify innovation. It is revealed that the strategy of innovative development of the agri-food and industrial complex should be determined on the basis of the state innovation policy, the main task of which remains to mobilize the potential of the scientific and technological potential of the industry for the technical and technological renewal of domestic industry and agro-industrial complex.
\end{abstract}

\section{Introduction}

Today, the development of the world economy is rapidly aimed at strengthening the economy of an innovative type. This trend can be traced by the example of economically developed countries. The knowledge-intensiveness of the products produced allows them to maintain the balance of the domestic market for goods on demand and supply, penetrate the leading world markets, force out and ruin the national producers. Under such circumstances, the Russian Federation must form an economy that will be aimed at the innovative development of industry and the agro-industrial complex [1].

An innovative economic system is a system in which technology is the main basis for its development.

Thanks to the formation of new markets for intellectual property, ideas and developments, the innovative development of the country's economy is ensured. Also, the old economic structures understand and carry out upgrades to improve quality.

At all stages of innovation modernization, the process of capital replacement takes place. The state finances science through infrastructure investments and research grants. Thus, 
research teams are beginning to compete with each other for obtaining funds for new developments [2]. The result of this stage is to get an excess of ideas. Some of these ideas may be unpromising, but this will create conditions for the capital replacement process. Inventions and patents are acquired by private firms, and their shares are sold to investors who are seeking to obtain super-profits. From this it follows that the innovative economy receives new funding already through private investment.

When developments and ideas develop and reach a higher level, they become interesting to larger corporations. So, even before the advent of prototypes, foreign investment began to be attracted, and the market became brisk. At the last stage, capital replacement by final consumers begins, which is made on the basis of new developments and interesting ideas.

Today, the innovative economy of the Russian Federation in the overall scale of the country's economy is extremely insignificant. According to Rosstat, in 2016 only $8.4 \%$ of organizations of the total number of organizations are engaged in innovative activities [3].

The equipment used in production is not capable of producing with higher capacities and moreover, it cannot even produce products that are competitive and consumed by the market. According to the CSR, "the production capacity of the Russian industry is outdated - $25 \%$ of the equipment used in the production was introduced before 2000, and the seventh part is already uncompetitive."

The lack of sufficient demand for new ideas in the domestic market of Russia impedes the development of innovations [4]. In order for an innovative economy to interest most business people and start to develop, first of all, modernization of industrial facilities is necessary, which will help stimulate demand for it.

The accelerated development of science and technology that has emerged in recent years, shortening the cycle of innovation in the economy and social sphere led to significant changes in the approaches to the formation and implementation of the state scientific and technical and innovation policy [5].

Today, one can hardly talk about effective strategic planning without scientific and technological forecasting. Forecasts of scientific and technological development, formed on a regular basis using foresight methods, become an integral component of the system of information and expert-analytical support making long-term decisions in developed and leading developing countries of the world, international organizations.

Russia is in line with the global trend of technological systems development forecasting at the national, sectoral, regional and corporate levels. From the end of the 1990s, using the foresight methodology, priority priorities are regularly directions of development of science, technology and engineering, and lists of critical technologies.

The Russian Federation, from the mid-2000s, a uniform methodology is gradually built up development of state forecasts of scientific and technological development. In recent years, the task of creating a national technological system. Forecasting is put at the highest state level [6]. In accordance with the Decree No. 1237 of the President of the Russian Federation dated May 12, 2009 "On the Strategy of the National the security of the Russian Federation until 2020 "state socio-economic».

The policy is aimed, in particular, at the formation of a system for forecasting science and technology development, strengthening the integration of science, education and production. Decree No. 776 of the President of the Russian Federation of May 7, 2012, "On the LongTerm State economic policy "contains a direct request to provide for measures to the formation of a technological forecasting system in the country.

At present, the Russian Federation is a resource-based country, and in the long-term decline in the volume of natural resources, it is necessary to raise its production, otherwise the situation will be unfavourable. Also negative is the fact that due to the innovation lag of the Russian Federation it represents low competition in the global market [7]. 
Intensive growth in food demand, increased consumption livestock products contribute to the long-term risks of instability in world agri-food markets. FAO and OECD estimates that as a result of population and per capita income by 2050 global production of agroindustrial complex should grow by $60-70 \%$ compared with the $2000 \mathrm{~s}$, which will mean the need production of additional 940 million tons of grain and 200-300 million tons of meat per year. Insofar as the main source of feed for growing beef and partly dairy cattle is a grain that is potentially edible, a higher consumption of meat means an increase in the load on ecosystems and less access to basic food for the general population [8].

At the same time, the average annual increase in agricultural productivity is expected at the level of below $1.7 \%$ and will be, according to existing forecasts, decrease, if there are not active introducing radical technological innovations. Population growth rates in the world accounts for $1.13 \%$, increases the average per capita food consumption. There is a long-term risk of exceeding the growth rate of demand over the growth rate of supply.

In this situation, Russia needs to take a firm position on the world markets for agricultural products, including both raw materials and products of deep recycling. Drivers for this are modernization of large enterprises, optimization use of agro climatic potential, the concentration of commercial agriculture in southern regions. Emerging economies should become priority markets (first of all, the Near and Middle East, South and South-East Asia, Central Africa, as well as the countries of the Eurasian Economic Union), where the purchasing power of the population growing faster than the capacity of national agriculture [9].

The growing concentration of population in large cities aggravates the problem of uninterrupted supply of urbanized food zones. According to the UN, the period from 1950 to 2014 , the share of urban population in the world increased from $30 \%$ to $54 \%$ and by 2050 will reach $66 \%$. Serious concerns in terms of stability large production and distribution systems causes the rapid growth of megacities with population over 10 million people. They are characterized by complex logistic infrastructure, high intensity of business processes, cascading effects in case of malfunctioning of certain elements of the infrastructure, critical dependence of residents on products produced outside such cities, above all food [10].

The problem of guaranteed uninterrupted supply of large urbanized food zones can be solved by developing infrastructure urbanized agriculture.

Today, technologies such as vertical farms and robotic greenhouse complexes, in Russia remain unclaimed due to high costs in conditions of extensive development of the agroindustrial complex [11]. But as far as technological progress in this area, the structure of costs associated with this technology can radically change. In this case, Russia will be forced to become importer of similar technologies, having missed a window of opportunity for their independent development.

An innovative economy will provide an opportunity for Russia to successfully expand sales markets and enter new international markets, since this sector contributes to the creation of new markets. Fostering a new market is easier than struggling with the old in the face of fierce competition.

According to the Institute of Statistical Studies and Economics of Knowledge (ISSEK) at the Higher School of Economics (HSE), in 2016 the level of innovation in industrial production in Russia was $9.2 \%$, a decrease of $0.3 \%$ compared with the previous year. This is the smallest indicator since 1999. Throughout the following years, this index was at a higher level, demonstrating the highest values in 2000, 2003 and 2004 . - 10.6\%, 10.3\% and 10.5\%, respectively.

The researchers explain the results obtained by reducing the intensity of innovation processes in high-tech industries.

In terms of the level and dynamics of innovation development, our industry is four to six times behind the leading industrial powers (Switzerland - 60.2\%, Belgium - 59.7\%; Germany 
- 58.9\%; Austria - 52.5\%, Finland - 52\%; Great Britain - 45.7\%) and 2-3 times from most of the states of Central and Eastern Europe.

Innovations that contribute to filling the domestic market with cheap, high-quality domestic products should be a priority for the development of industry and the agro-industrial sector [12].

In creating the innovative structure of industries, the decisive role should be played by the state. At the same time, state regulation of this process should be able to balance the interests of the participants of cooperation, stimulating or prohibiting one or other of its forms and directions. The states of those countries where they have found the best ways of such regulation give local entrepreneurs the opportunity to receive additional income, strengthen the scientific and technological base of industry and the agro-industrial sector, while not disturbing the balance sheets and the balance between innovation and tradition.

Innovative processes require significant investments. Therefore, started deteriorate in 2014 the investment climate in Russia (in 2015 and 2016 this process continued) entailed a decline innovation activity [13]. For improvement economic situation of the country's leadership it is necessary to remove obstacles in the way capital. The main obstacle for any investment, including investment in the innovation sector, according to S.D. Ageev, is a macroeconomic instability of Russia. This circumstance contributes to high investment growth Russian capital in foreign assets.

The situation in the country has worsened. But if these sanctions to the leadership of the country difficult to affect, it may well be try to improve the situation inside the country in areas that, along with macroeconomics determine the investment climate.

According to S. D. Ageev, this requires reducing corruption, supremacy law, transparency and clarity of regulatory legal framework protecting copyright right. So, now in front of Russia there is a task similar to the one that ours the country decided on the threshold of the XVIII and early XX centuries.

Russia is a country of a "catching-up civilization". For modern innovation growth we, first of all, do not have enough high-grade economic competition. It is this in all without exception, the developed world is always being the engine of innovative process-owls in the economy, because the pressure of competitors forced the entrepreneur to create principles.

New products and technologies, as well as seek other means of survival. In most sectors of the Russian the economy has developed oligarchic capitalism. And oligopoly, as is known, is of interest to owl in reducing competition due to price collusion or distribution of spheres of influence [14]. It eventually leads to inhibition development of society. Overcoming this barrier - the domination of the oligarchs in industries - is a condition for the transformation of the Russian capitalism from economy too few in economy for a mass entrepreneur. What tasks the government should solve to create conditions for the transition to innovation developmental path? First and foremost, the main thing is to help businesses in opening small and medium enterprises. Supporting the opening of small businesses, power besides increasing the number of new jobs and increase tax revenues to the budget, ensures the development and strengthening of competition in industries. This, in turn, should cause growing need for innovation and how consequence, the whole chain of innovative changes, since for the production of innovative innovative product is needed technology that is impossible without implementing innovative transformations throughout perimeter business model.

There is no universal innovation model that can be applied in all regions for any kind of innovation activities and at any time. Each region each state organizes a similar work, relying on own resources, based on the relevance of those facing them tasks. The question of how innovative the model fits a specific region, remains open, and the answer is determined by the features economic development [15]. 
All the above problems can be and you need to decide why you need to create appropriate conditions for investment activities - investing in growing Russia's innovative economy as a whole, and point-specific enterprises and manufactures.

A striking example is the model of the transformation of the agro-industrial complex in China. They began to reform the economy in 1979, and by the end of 2008 in the People's Republic of China (PRC), GDP grew by 15 times, and the average per capita income of the population - by 7.5 times. According to The World Bank's resource, in 2014, cereal production in China in 2014 was equal to 557 million metric tons, and this figure increases every year.

The Russian Federation has a huge agricultural potential. With only $2.2 \%$ of the world's population, it has $8.9 \%$ of world arable land, $2.6 \%$ of pastureland, $20 \%$ of world freshwater and $8.3 \%$ of mineral fertilizer production.

Despite the available resources, the prospects for the functioning of the domestic AIC are very incomprehensible. For the most part, they will depend on the state policy in the field of innovation in the agro-industrial complex and, of course, on the degree of integration of industry and the agro-industrial complex in the world market. Thus, in the concept of longterm socio-economic development of Russia developed by the Ministry of Economic Development of the Russian Federation until 2020, an innovative development scenario is envisaged, which will be accompanied by active structural shifts supported by a significant increase in the efficiency of resource use. According to their forecasts, the share of the innovation sector in GDP will increase from $10.5 \%$ in 2006 to $18.1 \%$ in 2020 (in 2006 prices) with a decrease in the share of the oil and gas sector from 19.7 to $12 \%$. Such changes will be ensured by the growth of innovation activity and supported by an increase in government spending from all sources of funding: for R \& D (Research and development) - up to $2.8 \%$ of GDP in 2015 and 4\% of GDP in 2020; on education - up to 4.8 and $5.2 \%$ of GDP, respectively. In the future, with such indicators of the Russian Federation may be competitive compared to European and Asian countries.

Nevertheless, there are conditions hindering the development of innovations in industry and agriculture. Rosstat notes a sharp decline in investment and a reduction in domestic demand. Other factors that have a negative impact include the reduction of state support for the agricultural sector and state financing of science and technology programs, underdevelopment of the credit system, high interest rates on loans, lack of innovation infrastructure and state innovation policies and strategies, insufficient training of personnel for industrial and agriculture organizations in areas of innovation management.

It is the presence of highly qualified and promising employees that is the basis for the quality performance of the institution and its employees issued by the founder of the task. Personnel planning programs can bring up specialists of the required level, which in addition to personnel assessment can include: rationing labour, introducing modern technologies, improving the material and technical base and organizing workplaces, improving system managers and specialists, streamlining the work process.

Now, taking into account the development trends of the world economy and Russia, there is a need to use public-private partnership mechanisms to attract capital and advanced technologies in the innovation economy, in particular, the agricultural and industrial sectors.

The main instruments of high-tech regulation are the development and implementation of long-term government programs; support for the modernization of production in priority areas for the country; ensuring industrial, sanitary and environmental safety; toughening of technological regulations and requirements for the rational use of natural resources. Also, the creation of special state funds for lending these processes in the agro-industrial and manufacturing sectors of the economy can be an important element in stimulating modernization processes. 
Thus, the formation of a full-fledged legislation in the innovation sphere, the creation of an effective system of stimulating innovation reproduction are the priority tasks of the state policy to expand the innovative possibilities for the development of Russian agricultural and industrial regions.

Also, an essential element in supporting innovation processes is the formation of a state innovation infrastructure.

In foreign countries, the state plays a significant role in creating a social infrastructure that includes the formation of an information system within the country. This can occur through the creation of any innovation distribution centres and consulting centres for the provision of business services to modernizers.

The innovative development of the agri-food and industrial complex has shown that financing from the state budget is still the main form of support in most countries.

Analysis of the current situation shows that the Russian Federation is necessary activation of innovation. The strategy of innovative development of the agri-food and industrial complex, its main goals, tasks and ways to support various innovative programs and projects should be determined on the basis of the state innovation policy, the main task of which is to mobilize the potential of the scientific and technological potential of the industry for technical and technological renewal of domestic industry and agriculture.

\section{References}

1. Abryutina M.S., Enterprise Economics (M .: Business and Service, 2017)

2. Avdeenko V.N., Production potential of an industrial enterprise (M .: Economy, 2015)

3. Aoki Masahiko, Corporation in the context of growing diversity: knowledge, leadership and institutions (Moscow: Gaidar Institute Publishing, 2015)

4. Arsenova E.V., Reference manual in the schemes on "Economics of organizations (enterprises)" (M .: Finance and Statistics, 2014)

5. Afanasyev M. V., Structural reforming of an economic object (methods, models and algorithms) (Moscow: High School, 2014)

6. Babich V.P., Economic preparation of the planning of scientific and technical progress (M .: Technika, 2018)

7. Barinova V.A., Institutional conditions of innovative development of the company (M .: Delo, 2014)

8. Belousov G. M., Means of organizational technology. Directory (M .: Economy, 2018) Borisova M.I., (M .: University book, 2014)

9. Byalkovskaya V.S., Worker on the economy. Reference manual (M .: Economy, 2015) Veblen T., The Theory of a Business Enterprise (M .: Delo, 2016)

10. Foreign economic activity of the enterprise (M .: Unity-Dan, 2016)

11. Volkov O.I., Enterprise Economics: Course of lectures. Series: Higher Education (Moscow: Higher School, 2016)

12. Wolfgang Mentzel, BWL Theory Fundamentals. Enterprise Economics (M .: Finance and Statistics, 2014)

13. Vorobyova A.V., Modern problems of internal self-financing (M .: Economy, 2017) 